\title{
A comparison of peripheral blood and buffy coat smear examination for the prediction of bone marrow relapse of acute lymphoblastic leukaemia in childhood
}

\author{
IAN M FRANKLIN* \\ From the Department of Haematology, Hospital for Sick Children, Great Ormond Street, London WC1
}

SUMMARY In an attempt to see if buffy coat smear examination might be an alternative to bone marrow aspiration for predicting relapse, 98 consecutive bone marrow aspirates from 96 children with acute lymphoblastic leukaemia were examined blind with buffy coat and peripheral blood from the same patients. The 28 bone marrow aspirates from children no longer on treatment were all normal, and routine aspirates would appear unjustified in these patients. Eight of the remaining marrows showed relapse, but only three were not predicted from the peripheral blood and buffy coat. In no case was buffy coat superior to peripheral blood in the detection of bone marrow relapse. Routine bone marrow aspirates are an inefficient way of diagnosing relapse in acute lymphoblastic leukaemia in childhood, despite their precision, and a prospective study is needed to $\mathscr{C}$ determine their value.

The repeated bone marrow aspirates used to confirm continuing remission during maintenance chemotherapy for acute lymphoblastic leukaemia are physically unpleasant and mentally distressing, especially for children. Recent work by Haworth et al ${ }^{1}$ suggests that routine bone marrow examination does not alter prognosis, but it continues to have a place in planning therapy and may help reduce morbidity by detecting relapsed disease earlier. Watson et $\mathrm{al}^{2}$ have proposed that routine bone marrow examination is not worthwhile and should be stopped.

Occasionally relapse is detected first in peripheral blood and the ability of this to predict relapse might be improved if more white cells could be examined, for instance by inspecting buffy coat smears. Such preparations are known to demonstrate more bone marrow elements than are usually seen in peripheral blood $^{34}$ and this study was carried out to see if the examination of buffy coat smears might be of practical use in the detection of bone marrow relapse, and so enable the numbers of bone marrow aspirates to be reduced.

\footnotetext{
${ }^{*}$ Present address: Department of Haematology, The Queen Elizabeth Hospital, Edgbaston, Birmingham B15 2TH.

Accepted for publication 22 September 1982
}

\section{Patients and methods}

Ninety-eight consecutive, non-selected bone marrow aspirates from 96 children with acute lymphoblastic $\overrightarrow{0}$ leukaemia attending the Leukaemia Clinic at the 3 Hospital for Sick Children, Great Ormond Street, were studied. Twenty-eight were from children no. longer on treatment, and 70 from 68 children ono treatment.

Blood and bone marrow smears were prepared routinely. Because of the small volume of many of the blood samples, buffy coats were prepared byફ the centrifugation of peripheral blood in a capillaryo tube for three minutes using a microhaematocrit centrifuge. After breaking the capillary on the plasmao side, the buffy layer was transferred to a glass slide, the cells resuspended in a drop of plasma, and the smear made as for a blood film.

All smears were collected, numbered andN examined blind after all aspirates had beeno performed, which was over a six-week period. Bone marrow relapse was defined as more than $5 \%$ blasts, and blood and buffy coat smears were assessed in@ terms of requiring "no action," of necessitating bone 0 marrow aspiration ("suspicious") or of showing the presence of leukaemia. The total haemoglobin, white cell count with differential, and platelet count were ${ }_{0}$ studied with each child's haematology flow chart to determine whether a bone marrow aspirate would be 
indicated from these values. To act as controls, the peripheral blood and buffy coat smears of 18 nonleukaemic children were examined with the patients.

\section{Results}

None of the 18 control buffy coat and blood smears was considered to be suspicious or to show disease.

Of the 28 bone marrow aspirates from children off treatment, none showed disease. One suspicious blood, and one buffy coat smear was noted as falsepositives. Both of these patients continue in remission.

There were eight relapsed bone marrow aspirates in the 70 samples from the 68 children on treatment for their leukaemia. Of the six florid relapses two were missed by blood and buffy coat smears, and peripheral blood count. Two were detected by both peripheral blood and buffy coat. In one case the peripheral blood was suspicious but the buffy coat preparation appeared normal, and in the sixth the blood count alone was abnormal. The two relapses missed had $12 \%$ and $65 \%$ blast cells in the marrow, and in those detected there were $61 \%, 95 \%, 76 \%$ and $55 \%$, the latter two being detected by the peripheral blood alone. Two marrow aspirates had only $7 \%$ and $8 \%$ blasts respectively and one of these relapses $(7 \%)$ was suggested by both peripheral blood and buffy coat. The other was not detected by either.

Thirteen marrows that were in remission were suspected of being in relapse from the examination of the other smears and blood counts. In nine cases the peripheral blood alone was suspicious, and in three only the buffy coat. In one child who had just successfully completed reinduction chemotherapy for recently relapsed disease both blood and buffy coat were suspicious. Of these 13 that may be considered false-positives for relapse, nine continue in complete remission over one year later. Only two relapses occurred within four months, both in the central nervous system, at one and four months respectively.

\section{Discussion}

Buffy coat smears did not provide any additional information to that obtained from peripheral blood. However, only three relapses were discovered that were not suggested by the peripheral blood. A reappraisal of routine marrow aspirates would appear warranted not only from the aspect of their contribution to outcome ${ }^{1}$ but also with regard to the small number of unexpected positives.

In the 28 children who had completed their chemotherapy, no case of relapse was detected, and so routine bone marrow aspiration would appear inappropriate for this group of patients. If the policy had been to inspect the peripheral blood and buffy coat before proceeding to the bone marrow aspiration two marrow aspirates would have been performed because of an incorrectly suspicious buffy coat or peripheral blood (one case each).

If the same policy had been in operation for the 70 aspirates from children on treatment the number of bone marrow aspirates performed would have been reduced to 16 . Examining only the peripheral blood count and smear would have lead to 14 aspirates of which five would have been in relapse. If the buffy coat had been examined first then six aspirates would have been performed with three relapses. In no case did buffy coat examination detect a relapse that was not suspected by the peripheral blood smear or count. Three cases of relapse would have been missed by both methods, these having $8 \%, 12 \%$ and $65 \%$ blast cells respectively. To detect these three cases it was necessary to do 56 aspirates not indicated by examination of the peripheral blood.

These data suggest that routine bone marrow aspiration in children on chemotherapy for acute leukaemia is of questionable value, particularly for children who have stopped treatment. Approximately half the relapses will be detected if a policy is adopted of careful study of peripheral blood films proceeding to bone marrow aspiration only if indicated. The detection of the remainder of relapses involves a much greater effort which may not be justified by the benefit achieved.

Haworth et al ' have questioned the value of routine bone marrow aspirates in terms of their contribution to prognosis, and since most children are seen at regular intervals for chemotherapy, the likely delay in diagnosing relapsed disease from peripheral blood may not be great. The potential savings in terms of children and parents anxiety and medical and nursing time would be considerable if routine bone marrow aspirates were discontinued, and this would appear reasonable in the light of the results obtained. A prospective study to determine whether early diagnosis of relapse by routine marrow aspiration is of any benefit would be valuable but as has been noted by Haworth et al, ' Watson et al, ${ }^{2}$ and in this study, such events are relatively infrequent and a large group of patients would be needed.

I would like to thank Dr JM Chessells and Miss Jeanette Stevens for their assistance with this study.

\section{References}

' Haworth C, Heppleston AD, Morris Jones PH, Campbell RHA, Evans DIK, Palmer MK. Routine bone marrow examination in the management of acute lymphoblastic leukaemia of childhood. J Clin Pathol 1981;34:483-5. 
${ }^{2}$ Watson DK, Robinson AE, Bailey CC. A reappraisal of routine marrow examination therapy of acute lymphoblastic leukaemia. Arch Dis Child 1981;56:392-404.

${ }^{3}$ Efrati P, Rosenszajn L. The morphology of buffy coat in normal human adults. Blood 1960;16:1012-9.

${ }^{+}$Efrati P, Rosenszajn L, Shapiro E. The morphology of buffy coat from cord blood of normal human newborns. Blood 1961;17:497-503.

Requests for reprints to: Dr IM Franklin, Department of Haematology, Queen Elizabeth Hospital, Birmingham, B15 2TH, England.

\section{The January 1983 issue}

\section{THE JANUARY 1983 ISSUE CONTAINS THE FOLLOWING PAPERS}

Cerebrospinal fluid concentrations of hypoxanthine, xanthine, uridine and inosine: high concentrations of the ATP metabolite, hypoxanthine, after hypoxia RA HARKNESS, RJ LUND

Application of reflectance spectroscopy to the estimation of uric acid, urea and glucose: an evaluation of the Ames Seralyzer JF STEVENS, RG NEWALL

Serum copper: a marker of disease activity in rheumatoid arthritis AAR YOUSSEF, B WOOD, DN BARON

Value of copper-associated protein in diagnostic assessment of liver biopsy P GUARASCIO, F YENTIS, U CEVIKBAS, B PORTMANN, R WILLIAMS

Haemolytic-uraemic syndrome complicating longterm mitomycin $\mathrm{C}$ and 5-fluorouracil therapy for gastric carcinoma J CROCKER, EL JONES

Macroglobulinaemia and intestinal lymphangiectasia: a rare association M HARRIS, IE BURTON, JH SCARFFE

Impaired production of mononuclear cell procoagulant activity in chronic lymphocytic leukaemia S CORTELLAZZO, P VIERO, T BARBUI, M COLUCCI, N SEMERARO

Stability of cyclosporin $A$ in human serum JM SMITH, JM HOWS, EC GORDON-SMITH

Analysis of large-cell lymphomas using monoclonal and heterologous antibodies PVAN DER VALK, G VAN DEN BESSELAAR - DINGJAN, M DAHA, CJLM MEIJER

Prognostic value of tumour thickness in cutaneous malignant melanoma IONA JEFFREY, P ROYSTON, C SOWTER, G SLAVIN, A PRICE, A POMERANCE, S GOOLAMALI, D PINTO

Intermediate filaments in smooth muscle tumours DJ EVANS, IA LAMPERT, M JACOBS

Coeliac disease, adenocarcinoma of jejunum and in situ squamous carcinoma of oesophagus CJ O'BRIEN, S SAVERYMUTTU, HJF HODGSON, DJ EVANS
Neuroblastoma arising in a mature cystic teratoma of the ovary HAS REID, JD VAN DER WALT, H FOX Intestinal lactase, sucrase and alkaline phosphatase in relation to age, sex and site of intestinal biopsy in 477 Irish subjects R KEANE, JG O'GRADY, J SHEIL, FM STEVENS, B EGAN-MITCHELL, B MCNICHOLL, CF MCCARTHY, PF FOTTRELL

Comparison of selective media for isolation of Campylobacter jejuni/coli FJ BOLTON, D COATES, PM HINCHLIFFE, L ROBERTSON

Household pets as a potential reservoir for Clostridium difficile infection SP BORRIELLO, PAULINE HONOUR, T TURNER, FIONA BARCLAY

Isolation of Clostridium difficile from patients and the environment of hospital wards HELEN MALAMOU-LADAS, S O'FARRELL, JQ NASH, SOAD TABAQCHALI

Relative carriage rates of nuclear dehydrogenating clostridia in two populations of different colorectal cancer risk SP BORRIELLO, BS DRASAR, A TOMKINS, MJ HILL

Biotyping of Haemophilus using API $10 \mathrm{~S}$ - an epidemiological tool? S MEHTAR, SA AFSHAR

Detection of complement fixation by enzyme linked immunosorbant assay (COMPELISA) PM HINCHLIFFE, L ROBERTSON

Use of the Phoenix system for bacteriology JENNIFER PERRY, DA MITCHISON, JH DARRELL

An assessment of environmental contamination arising from the use of equipment for carrying out the ELISA technique in microtitre plates GJ HARPER

\section{Technical method}

Haematoxylin counterstaining of immunofluorescence preparations M CHILOSI, G PIZZOLO, C VINCENZI

\section{Letters to the Editor}

Book Reviews

Some new titles

Notice

Copies are still available and may be obtained from the PUBLISHING MANAGER.

BRITISH MEDICAL ASSOCIATION, TAVISTOCK SQUARE, LONDON WC1H 9JR. price $£ 5.00$, including postage 